\title{
INTERACTIVE LEARNING MEDIA FOR DYSLEXIC STUDENTS OF ELEMENTARY SCHOOL
}

\author{
Tita Rosita ${ }^{1}$, Tuti Alawiyah ${ }^{2}$, Endang Rochyadi $^{3}$, Sunardi $^{4}$ \\ ${ }^{1}$ IKIP Siliwangi \\ ${ }^{2}$ IKIP Siliwangi \\ ${ }^{3}$ Universitas Pendidikan Indonesia \\ ${ }^{4}$ Universitas Pendidikan Indonesia \\ ${ }^{1}$ titarosita794@gmail.com, ${ }^{2}$ tutyrahman@ yahoo.id, ${ }^{3}$ endangrochyadi@upi.edu \\ ${ }^{4}$ nardilembang@upi.edu
}

\begin{abstract}
The purpose of this study is to develop web-based learning media to improve the reading comprehension of dyslexic students. Dyslexia is a condition caused by neurobiological abnormalities that are characterized by difficulty in recognizing words accurately in spelling and inability to encode symbols which lead to reading disorder. The research method used is research and development. This research develops web-based learning media called LexiRoom learning applications. The LexiRoom web was trialed to dyslexic students of the fourth grade of elementary school and obtained effective results to help students to have a better comprehension of words and sentences within a paragraph.
\end{abstract}

Keywords: Interactive Learning Media, Dyslexia.

\begin{abstract}
Abstrak
Tujuan penelitian ini yaitu untuk mengembangkan media pembelajaran berbasis web untuk meningkatkan pemahaman membaca peserta didik dengan hambatan disleksia. Disleksia adalah suatu kondisi yang disebabkan karena kelainan neurobiologis yang ditandai dengan kesulitan mengenali kata dengan akurat dalam pengejaan dan dalam kemampuan mengode simbol sehingga mempengaruhi kemampuan membaca. Adapun metode penelitian yang digunakan yaitu research and development. Penelitian ini mengembangkan media pembelajaran berbasis web dengan aplikasi belajar yang diberi nama LexiRoom. Uji coba web LexiRoom dilakukan pada siswa dengan hambatan disleksia kelas empat Sekolah Dasar dan diperoleh hasil yang efektif untuk membantu meningkatkan siswa dalam belajar memahami kata dan kalimat yang ada pada sebuah paragraph.
\end{abstract}

Kata Kunci: Media Pembelajaran Interaktif, Disleksia.

\section{INTRODUCTION}

Ministry of Education and Culture Regulation No. 65 of 2013 states that the learning process in the education unit should be carried out interactively, inspirational, fun, challenging, and motivating students to actively participate, as well as providing sufficient space for craftsmanship, creativity, and independence in accordance with their talents, interests, physical and psychological development of students.

Research done by Pelupessy, E. T., \& Agustin T, R.H.P. (2014) shows that the effectiveness of learning material submission using learning media reaches $86 \%$. The results of this study indicate that media learning is very effective to help the absorption of learning materials. Kemp \& Dayton (in Arsyad, 2013: 39) classify media into eight types; print media, 
display media, overhead transparent images, audiotape recordings, slide series and film strips, multi-image presentation, video, and live film footage, and computers. Overall, the implementation of e-learning covers almost all types of media in the technology of learning.

A book of E-learning Tools and Technologies: A consumer's guide for trainers, teachers, educators, and instructional designers written by Willian Horton (2003) elaborates that e-learning is a means of education which is designed with media that can be accessed from properly equipped computer terminals, and other means of Internet-accessible technology. One example of e-learning is the Learner-led e-Learning category. This category can be easily combined and enable broader development. Learner-led e-Learning is easy for students to use for the purpose of interactive learning. A learning media is considered to be interactive if the user is not only able to see and hear but also directly interact with it. Learning media should incorporate communication, self-motivation, efficiency, and technology.

Web learning or web-based learning is one example of e-learning. Nowadays, elearning develops rapidly. According to Zhang (2004), e-learning is technology-based learning where learning material is delivered electronically to distance learners through computer networks. This media requires students to keep themselves motivated because of limited social interaction. Thus, web-based learning should be developed as interesting as possible.

Nichols (2003) considers e-learning as the use of various technology tools both webbased (network), distributed web, or network capabilities for educational purposes. The application of e-learning also includes digital materials storage and distribution.

Educational goals will be achieved if the learning process is carried out through the development of a teaching tool. Web-based learning development is a series of processes or activities carried out to produce a learning tool based on existing development theories. Development is a process of creating, trying, and producing appropriate learning materials (American Society for Training and Development, 2007).

According to Akker, J. Van den. (1999) there are two objectives of development research. Firstly based on development to obtain a product prototype, and secondly formulating methodological suggestions for designing and evaluating the prototype. The prototype in this study aims to develop learning media with web-based to improve reading comprehension of dyslexic students.

Dyslexic students often experience difficulties in their metacognitive aspect (Reid, 2011; Tunmer and Chapman, 2000). They need support to adopt learning behaviors that are appropriate for learning. The learning success of dyslexic students is sometimes inhibited by 
the problem of their working memory (Reid, 2003). The problem of working memory will lead to a short span of concentration of dyslexic students.

Dyslexia according to Aphroditta (2012), is cognitive impairment in the form of reading disorder, dyslexia people have trouble reading a good pace without making mistakes because they have difficulty in recognizing letters which look like. Dyslexic students possess normal IQ as well as their other abilities are also good but have a hard time with reading comprehension, spelling, and writing. Thus, dyslexia is not a problem of intelligence. Dyslexic students are just as smart as the other students but they have problems with language.

Reading disorders of dyslexic students may impact their life. It does not just affect their learning activities at school but also to their social interaction, memory, and their capability in dealing with stress. In some cases, dyslexic students tend to avoid reading both out loud and to themselves and sometimes get anxious even feeling frustrated when reading. So that dyslexic students need an interactive learning media that can help them to read easier.

The purpose of this study is to discover the use of learning media named lexiRoom in improving the reading comprehension of dyslexic students. The specific objective of this study is to elaborate on how the lexiRoom application can be implemented in the reading activity of dyslexic students of Elementary School.

\section{METHOD}

This research uses research and development procedures. Research and development is a process or steps to develop a new product or improve an existing product. The products produced in this study are web-based e-learning learning media to improve the reading comprehension of dyslexic students.

Research and development according to Borg and Gall (in Sugiyono 2009) covers several stages, those are (1) potential problems, (2) data collection, (3) product design, (4) design validation, (5) design revision, (6) product trials, (7) product revisions, (8) product trials, (9) product revisions, (10) mass production. The stages carried out by the researcher only up to product trial which was formulated into eight stages, namely on the trial use of a web-based interactive learning media product.

Interactive learning media developed by researchers consist of material that covers aspects of mechanical and understanding skills. The general description of this media is first, the media consist of recognition of the form of letters, recognition of linguistic elements, 
recognition of the relationship of sound and letters, as well as slow reading speed systematically arranged according to the needs of elementary school students.

\section{RESULTS}

This research develops Web-based learning media with a learning application named LexiRoom, this application is carried out by developing a software methodology. As a learning application, LexiRoom is able to help dyslexic students to easily read the subject matter since there is a voice application on the Web. The display of voice options in several

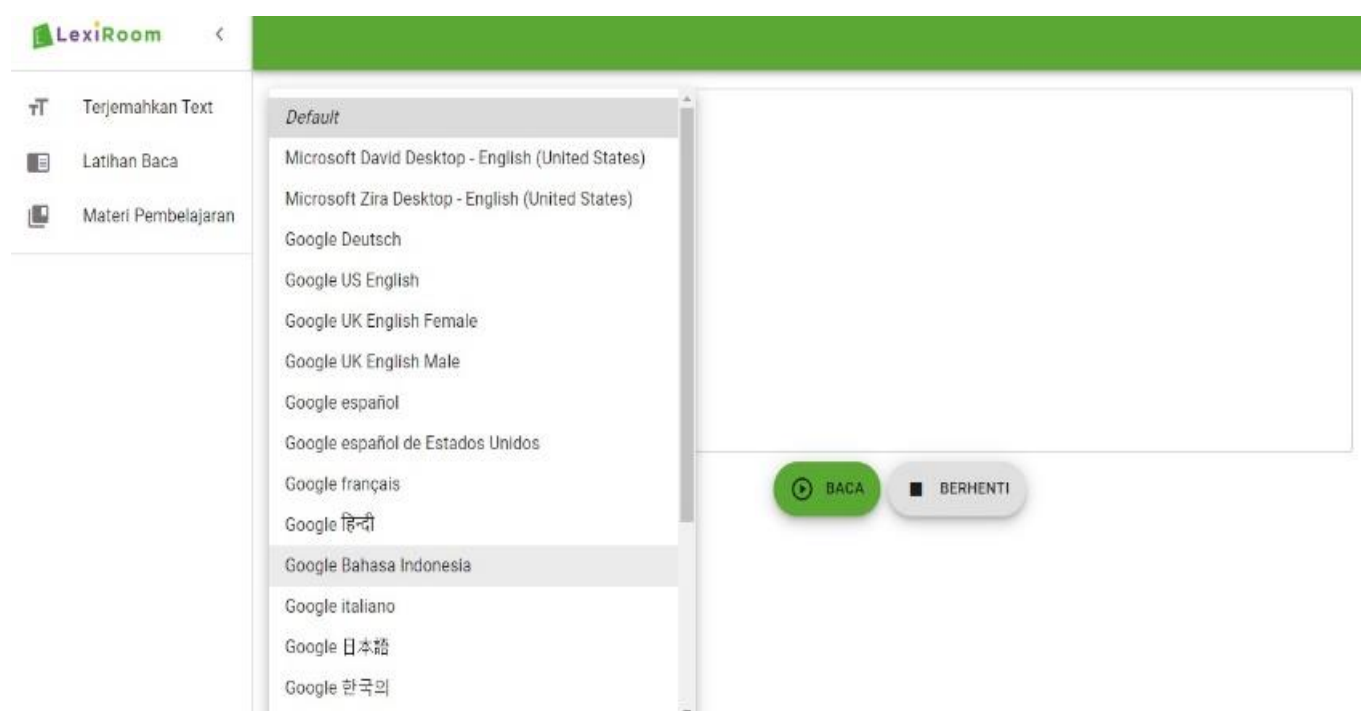

Figure 1. Display of voice options in several languages on the LexiRoom Web

To facilitate learning, study material can also be downloaded on the LexiRoom web. After the material is downloaded, students can copy the material into the Indonesian text, so then a voice will appear. The appearance of the material in PDF format is as follows:

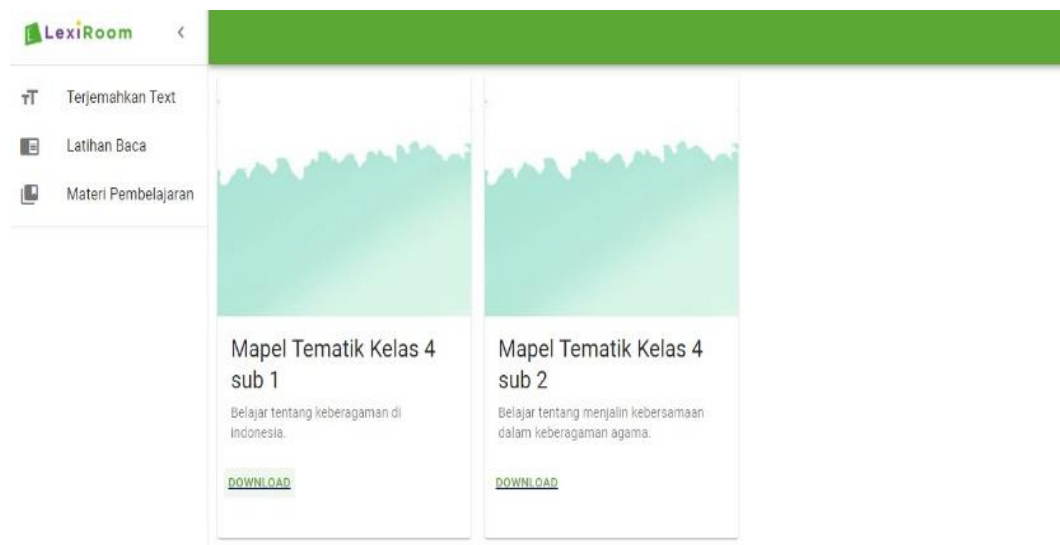


Figure 2. Web Display in pdf format for Class 4 SD material

The LexiRoom application is then tested to the 4th-grade dyslexic students of AlGraham Elementary School. The student was asked first to read a paragraph from the Thematic Class 4 subject book Subtheme 1 Cultural Diversity of My Nation without using the LexiRoom application. The paragraph to read is:

\section{Cultural Parade}

The Cultural Parade is very interesting for residents of Kampakan Babakan. This parade always displays the diversity of Indonesian culture. Udin and friends were never bored waiting for the parade to pass by. This year they came to the square to see the parade. Udin's grandfather also looked patiently waiting. There was the sound of a drum indicating the parade was getting closer.

Based on observation has been conducted, it was found that dyslexic students still read the word such as "Babakan" becomes "Papakan", through becomes "tour", grandfather becomes "kakeu", signifying becomes "instilling". Then, when they were asked to explain the paragraph they have read, students simply answer "there is a parade" without further information. The student's duration of reading a paragraph is 1 minute 34 seconds, with quite slow voice and tends to be careful during reading. Meanwhile, when the other non-dyslexic students were asked to read the same paragraph, it took only 25 seconds to finish it.

Knowing the dyslexia students' obstacles in reading, the LexiRoom application is then tested to them using voice applications that are on the Web. As a result, students found it easier to identify words that are difficult for them to read and have a better understanding of the meaning of the paragraph. Students also seemed to realize some misread words beforehand, so they were able to do self-correction when they found mistakes in reading. Students also said that Web LexiRoom made them easier in understanding learning materials compared to their own reading.

\section{DISCUSSION}

The symptoms of dyslexia are different from one person to another. Marshall (2001) mentioned some symptoms of dyslexia students which can be identified by a school in order to give support to them. 1) that appear in children with dyslexia barriers, such as seeing a few letters in reverse (from back to front). 2) Unable to distinguish letters that have similar shapes, such as the letters o, e, and c, as well as letters that have similar shapes but different orientations, such as letters $\mathrm{b}, \mathrm{p}, \mathrm{d}$, and $\mathrm{q}$. The initial and the middle letters seem to be mixed up and disorganized. 3) They have difficulty in putting letters and words in the correct order as 
well as reading letters in reverse ( from behind), such as the word "purg" or "bird" becomes "drib". 4) They are able to recognize letters but having poor spelling abilities. 5) They are probably able to connect letters and pronunciation of words but having difficulty in recognizing words they have seen before although they have seen those words many times. 6) Since they also have poor short term memory, it is difficult for them to remember what they have read so it must re-read repeatedly.

In some dyslexic students, those symptoms mentioned above even impact their more complex skills such as grammar comprehension, reading comprehension, reading fluency skills, understanding structure, and writing skills.

Researchers state some possible causes of dyslexia. 1) Scientists have found genes linked to problems with reading and processing language. 2) From a neurological point of view, every child enables them to have good spoken and written language including reading when their neuro-biological allows processing, but the dyslexic student since they have deficit vocabularies then it is not easy for them to predict and better understand words. Thus, it can be said that the trigger of dyslexia is a neurobiological disorder, which is characterized by difficulty in recognizing words correctly, both in spelling and coding of symbols.

Current research shows there are anatomical differences between dyslexic children's brains and non- dyslexics, namely in the temporal-parietal-occipital area. Functional Magnetic Resonance Imaging Examination which is used to examine the brain during reading activities shows that the brain activity of dyslexic students, especially in terms of processing input letters or words that are read and then "translated" into meaning is very different from non-dyslexics.

Some other studies also found that there are brain differences between dyslexic and non-dyslexic students. The differences occur in the area of the brain which functions as the key reading skills area. Those skills are knowing how sounds are represented in words and recognizing what written words look like.

\section{CONCLUSION}

LexiRoom is a web-based learning media application as a research product using development research procedures. Based on the trial results of the LexiRoom web application learning media, it was found that the application is effective to help dyslexic students to have a better comprehension of words and sentences within a paragraph. Thus, the development of LexiRoom learning media can be part of the dyslexic student learning process. 
However, the LexiRoom application has been used only for the purpose of this research and has not been revised as well as has not yet been mass-produced. So it is hoped that in future research, LexiRoom can be further developed with interactive materials to facilitate dyslexic students in learning.

\section{REFERENCES}

Akker, J. Van den. (1999). Principles and Method of Development Research. London: Kluwer Academic Publisher.

Aphroditta. (2012). Panduan lengkap orangtua dan guru untuk anak dengan disgrafia (kesulitan menulis). Yogyakarta: Javalitera.

Arsyad, A. (2013). Media Pembelajaran. Jakarta: PT. Raja Grafindo Persada

Chapman, J.W., Tunmer, W. E. \& Prochnow, J.E. (2000). Early reading-related skills and performance, reading self-concept, and the development of academic self-concept: a longitudinal study. Journal of Educational Psychology, 92, 4, 703-708

Horton, William \& Horton, Katherine. (2003). E-Learning Tools and Technologies: A consumer guide for trainers, teachers, educators, and instructional designers. USA: Wiley Publishing, Inc.

Meyer, A., \& Rose, D. H. (2005). The future is in the margins: The role of technology and disability in educational reform. In D. H. Rose, A. Meyer, \& C. Hitchcock (Eds.), The universally designed classroom: Accessible curriculum and digital technologies (pp. 13-35). Cambridge, MA: Harvard Education Press.

Pelupessy, E. T., \& Agustin T, R. H. P. (2014). Pengembangan media pembelajaran berbasis e-learning pada mata kuliah fisika 1 untuk meningkatkan efektifitas belajar mahasiswa. Jurnal Pendidikan Teknik Elektro, 3(2).

Reid, R., Lienemann, T. O., \& Hagaman, J. L. (2013). Strategy instruction for students with learning disabilities (Second Edi). New York: Guilford Publications.

Rose, D. H., \& Meyer, A. (2002). Teaching every student in the digital age: Universal design for learning. Alexandria, VA: Association for Supervision and Curriculum Development.

Sugiyono. (2009). Metode penelitian kuantitatif, kualitatif dan $R \& D$. Bandung : Alfabeta

Weinstein, Lissa. (2008). Living with Dyslexia. Bandung: Qanita. 